\title{
Foraging theory provides a useful framework for livestock predation management
}

Haswell, Peter; Shepherd, Elizabeth; Stone, Suzanne A.; Purcell, Brad; Hayward, Matthew

\section{Journal for Nature Conservation}

DOI:

10.1016/j.jnc.2019.03.004

Published: 01/06/2019

Peer reviewed version

Cyswllt i'r cyhoeddiad / Link to publication

Dyfyniad o'r fersiwn a gyhoeddwyd / Citation for published version (APA):

Haswell, P., Shepherd, E., Stone, S. A., Purcell, B., \& Hayward, M. (2019). Foraging theory provides a useful framework for livestock predation management. Journal for Nature Conservation, 49, 69-75. https://doi.org/10.1016/j.jnc.2019.03.004

\footnotetext{
Hawliau Cyffredinol / General rights

Copyright and moral rights for the publications made accessible in the public portal are retained by the authors and/or other copyright owners and it is a condition of accessing publications that users recognise and abide by the legal requirements associated with these rights.

- Users may download and print one copy of any publication from the public portal for the purpose of private study or research.

- You may not further distribute the material or use it for any profit-making activity or commercial gain

- You may freely distribute the URL identifying the publication in the public portal ?
}

Take down policy

If you believe that this document breaches copyright please contact us providing details, and we will remove access to the work immediately and investigate your claim. 


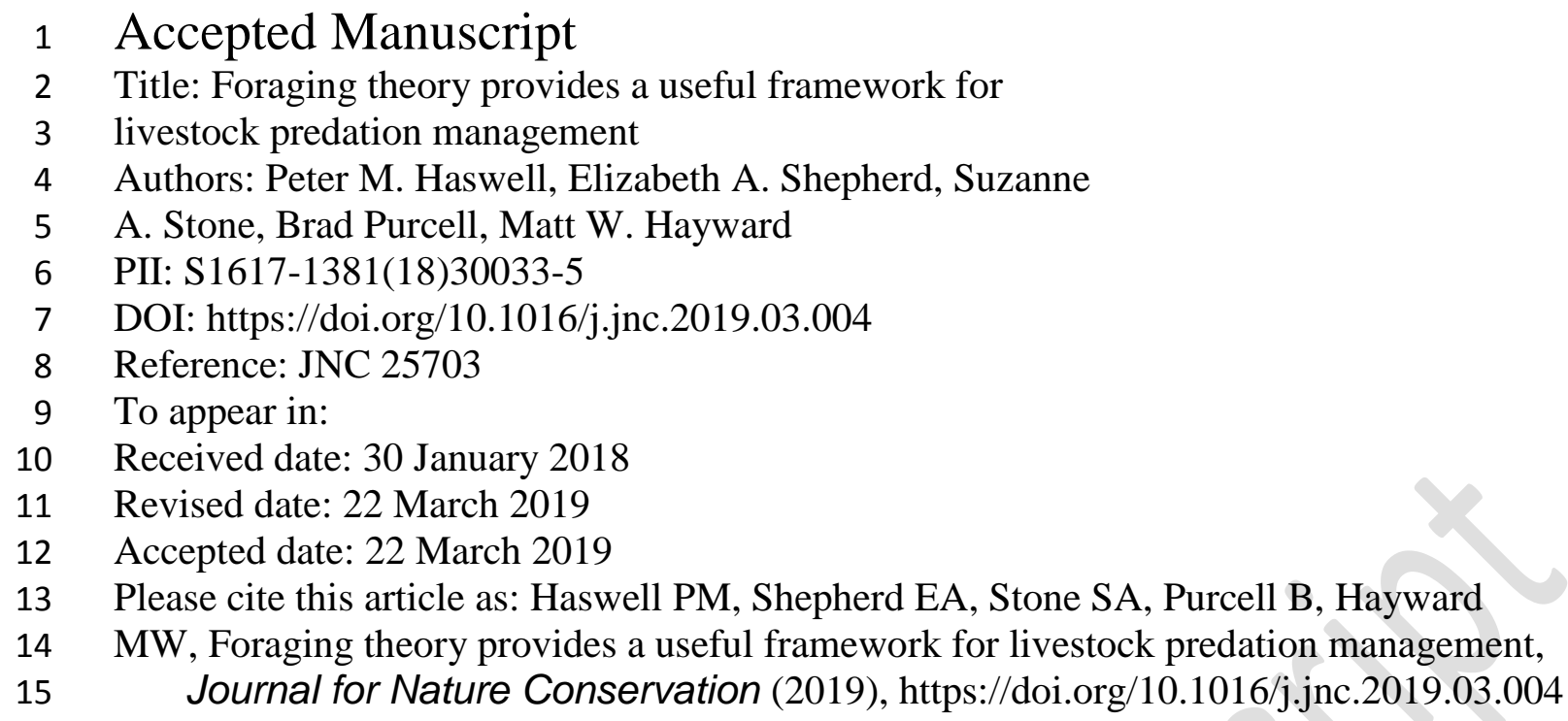


31 Peter M. Haswell ${ }^{\text {a }}$, Elizabeth A. Shepherd ${ }^{b}$, Suzanne A. Stone ${ }^{c}$, Brad Purcell $^{\text {d}}$, Matt W. Hayward ${ }^{\text {ae }}$

$32{ }^{a}$ School of Biological Sciences, Bangor University, Bangor, Gwynedd, LL57 2UW, UK.

$33{ }^{\mathrm{b}}$ The sustainability lab, Bangor University, Bangor, Gwynedd, LL57 2UW, UK

$34{ }^{\mathrm{c}}$ Department of Field Conservation, Defenders of Wildlife, 1130 17th St. NW, Washington, DC

35 20036, USA.

$36 \quad{ }^{\mathrm{d}}$ PO Box 589 Dubbo, NSW 2830 Australia

$37{ }^{\mathrm{e}}$ School of Environmental and Life Sciences, University of Newcastle, Callaghan NSW Australia

38 2308; Centre for African Conservation Ecology, Nelson Mandela Metropolitan University, Port

39 Elizabeth, South Africa; and Centre for Wildlife Management, University of Pretoria, South Africa.

40 Corresponding author: Peter M. Haswell, p.m.haswell@bangor.ac.uk

41

42

43

44

45

46

47

48

49 


\section{Abstract}

51 A societal shift toward plant dominant diets and a reduction in livestock rearing could have broad social, environmental and conservation benefits. Livestock husbandry, however, has a wealthy cultural history, strong support and high consumer demand. It is therefore likely to continue as a major land use and conservation issue for predators. From a producer's perspective, the primary goals of livestock protection are maximising, or at least maintaining, production by minimising losses and mitigating detriment to stock welfare. Lethal removal of predators remains a commonplace solution. Such management measures are questionable as they raise animal welfare and conservation concerns, risk inhibiting ecological processes, are often expensive, and in some circumstances, exacerbate livestock predation problems. Non-lethal alternatives can facilitate co-existence between livestock farmers and predators, ideally reducing the ecological impact of pastoralism and achieving conservation goals. The need for rigorous study of non-lethal approaches has however been recently highlighted. Tools and methods involved in livestock protection, as well as the theoretical basis of how we perceive and manage the problem, require deeper consideration. Non-lethal approaches require knowledgeable implementation and an effective decision making system is a prerequisite for successful practice. Livestock predation and its prevention are fundamentally influenced by the underlying principles of foraging ecology and risk theory. We propose that manipulating elements of

67 Brown's (1988) quitting harvest rate model provides a useful conceptual framework for reducing livestock predation and encouraging coexistence.

\section{Keywords}




\section{Introduction}

While perhaps politically and industrially unfavourable, there is justifiable discourse and concern regarding the social and environmental footprint of the livestock industry (Westhoek et al. 2014; Hallström, Carlsson-Kanyama \& Börjesson 2015). Public concern with livestock welfare presents a longstanding contention (Deemer \& Lobao 2011). Resource efficiency and issues relating to health and nutrition present direct concerns for effectively meeting nutritional needs of a growing human population through livestock products (Baroni et al. 2007; Westhoek et al. 2014; WWF 2016).

Disease transmission and antibiotic resistance pose additional health concerns for humans, livestock and wildlife (Thompson 2013; Gottdenker et al. 2014; Hudson et al. 2017). Pastoralism's freshwater consumption and land use are also intensive, with habitat modification, ecological degradation, emissions, effluent and contribution to climate change all providing grave concerns (Baroni et al. 2007; Westhoek et al. 2014; Hallström, Carlsson-Kanyama \& Börjesson 2015). Alongside indirect implications for wildlife conservation, livestock directly compete with and have replaced much wild biodiversity (Bar-On, Phillips \& Milo 2018).

Some champion the potential conservation benefits of well managed livestock but often neglect to place such benefits in context, failing to draw comparisons with unmodified systems (Franzluebbers et al. 2012). The overall benefits for wildlife conservation are however contentious; livestock grazing, for example, can adversely affect species conservation, ecosystem structure, function and composition (Reading \& Jofre 2015; Eldridge et al. 2016; Sharps et al. 2016). Livestock biomass now far exceeds that of wild mammals and competition for forage can negatively impact both wild herbivores and their predators (Latham 1999; Bar-On, Phillips \& Milo 2018).

Native predators can be completely excluded from pastoral landscapes or exterminated altogether, e.g. large carnivores in the British Isles (Brown, McMorran \& Price 2011). Cultural and social bias against predators may often exist in rural areas, regardless of personal experience with livestock predation (Chavez, Gese \& Krannich 2005). Actual impacts can be small relative to other factors including disease, birthing problems, weather and accidents (Breck \& Meier 2004; Dar et al. 2009). A small 
proportion of producers in predation hotspots may, however, absorb the majority of losses, increased husbandry costs and decreased animal performance (Breck \& Meier 2004; Shelton 2004). Damage to livelihoods can reduce support for conservation initiatives (Anthony 2007; Anthony, Scott \& Antypas 2010). Livestock predation often results in disproportionate deaths of the animals deemed responsible and persecution of predators is common (Meriggi \& Lovari 1996; Shivik 2006; Eggermann et al. 2011). Lethal control of predators to pre-empt or in response to livestock predation has become common management in many contexts (Macdonald \& Baker 2004; Treves et al. 2006).

The simplest way to resolve many of these problems would be to substantially reduce livestock production and move to plant dominant diets on a societal level (Eshel et al. 2014; Poore \& Nemecek 2018). Changing consumer habits should not be overlooked as a potential nature conservation tool. Suitable damage related taxation may offer some assistance to this end (Springmann et al. 2017).

Discouraging unnecessary consumption and encouraging financial divestment by consumers offers an additional route to achieving sustainability (Ripple et al. 2017). Such a large-scale transition may, however, prove difficult where habitat, technology, international trade, culture, affluence or knowledge makes livestock products one of few viable food production methods or an easily accessible dietary option. Livestock farming also has a long and enduring cultural significance (McClure 2015; Holmes 2016; Pitikoe 2017). High levels of meat, egg and dairy consumption are prevalent in many societies and a global shift away from this is currently unlikely, with human populations and demand for animal products increasing globally (Kearney 2010; Westhoek et al. 2014). Livestock production is likely to continue as a major land use and livestock predation remains an issue for both pastoralists and conservationists.

The ecological impacts, efficiency and morality of lethal control are questionable (Treves, Krofel \& McManus 2016). Lethal control of predators and decline in their numbers can result in loss of ecological services and stability (Wallach et al. 2010; Ripple et al. 2014). Lethal control may not always be economically viable if loss of regulatory services by predators results in high costs where wild herbivores compete for forage with domestic stock (Wicks \& Allen 2012). Lethal control can also disrupt social structure, exacerbating livestock predation problems (Wallach et al. 2009), or lead 
to compensatory reproduction, thereby minimising the effect of control (Minnie, Gaylard \& Kerley 2016; 2017). A range of non-lethal alternatives exist that can assist mitigation of livestock predation problems and encourage coexistence (Shivik 2006; Stone et al. 2017). Societal preference for coexistence has led to greater adoption of such approaches (Chapron et al. 2014). Non-lethal livestock predation management can, although may not always, be equally or more effective than lethal control of predators (McManus et al. 2015; Stone et al. 2017; van Eeden et al. 2018a). Some non-lethal tools have been well tested but further robust experimentation is required to assess efficacy, encourage producer adoption and guarantee return on investments (Eklund et al. 2017; Scasta, Stam \& Windh 2017; van Eeden et al. 2018b).

We refer readers to van Eeden et al. (2018b) for a useful synthesis of the current evidence base but recognise that in practice, one approach is rarely used in isolation of others, effectiveness will be context dependent and action is still required while the necessary testing of tools is conducted. Practitioners require a holistic and adaptive management system to more easily and effectively implement non-lethal programmes across a broad range of contexts. Applying existing scientific theory to real world issues should prove productive for both study and practice. The predation and protection of livestock are fundamentally influenced by the principles of both foraging and risk theory. We propose that Brown's (1988) quitting harvest rate model provides a useful theoretical framework for managing livestock predation and achieving conservation goals.

\section{Brown's (1988) quitting harvest rate model as a management framework}

Foraging theory suggests animals attempt to make the best of foraging scenarios by trading-off costs against benefits (Emlen 1966; MacArthur \& Pianka 1966; Charnov 1976). Decisions to prey upon livestock instead of wild prey may be based in energetics (Polisar et al. 2003), but there is little evidence of predators preferentially hunting livestock where it has been tested (Lyngdoh et al. 2014; Hayward et al. 2017). Brown's (1988) quitting harvest rate model provides a useful framework with which to examine the mitigation of livestock harvest by predators. Where food patches are depletable, animals should abandon patches once gains (H) become equal to or fall below costs (Brown 1988; 
Brown \& Kotler 2007). The concept is described in the equation $\mathrm{H}=\mathrm{C}+\mathrm{P}+\mathrm{MOC}$, where $\mathrm{H}=$ harvest rate (food gain per unit time), $\mathrm{C}=$ energetic costs (to obtain food), $\mathrm{P}=$ predation costs (cost/likelihood of losing fitness by interacting with predators) and MOC $=$ missed opportunity costs (food or fitness enhancing benefits available elsewhere) (Brown 1988; Brown \& Kotler 2007). Like Berger-Tal et al. (2009), we also included risk of injury (RI) or mortality (e.g. from objects like electric fencing, terrain ruggedness, the stock themselves, or a device worn by stock) as an additional cost that may be incurred during livestock predation but discuss it alongside $\mathrm{P}$ for ease of discussion and implementation.

From a producer's perspective, the primary goals of livestock protection are maximising, or at least maintaining, production by minimising losses and mitigating detriment to stock welfare. Practitioners and wildlife managers should aim to manipulate predator foraging behaviour to reduce livestock predation; intentionally causing predators to quit livestock patches more quickly and harvest less, or ideally, no stock (Table.1). Ideally, livestock could be made so unprofitable comparable to wild prey that they become less preferable and are rarely preyed upon. Here we highlight considerations that may offer some utility but should be contemplated only in relation to individual context by giving thought to all model components.

\section{Harvest rate $(H)$}

171 Initial harvest rate $(\mathrm{H})$ of livestock patches could be reduced to increase how quickly predators give

172 up on livestock patches. Predators can be attracted to anthropogenic food subsidies, adapting their

173 behaviour to utilise them (Ciucci et al. 1997; Newsome et al. 2014; Morehouse \& Boyce 2017).

174 Refuse sites in pastoral areas are likely to attract predators and lead to increased conflict (Wilson et al. 175 2006; Kolowski \& Holekamp 2008). Removal of carcasses, livestock pits or waste dumps in the 176 vicinity of livestock would provide sensible starting points to reducing patch attractiveness. Herd size 177 (i.e. food availability) may also provide an attractant. Farms with larger herds may be more likely to 178 experience livestock predation (Treves et al. 2004; Bradley \& Pletscher 2005; Pimenta et al. 2017). 
179 Herd size could potentially be reduced, although there is likely an economic disincentive to do so

180 (Pimenta et al. 2017).

181

182

183

184

\section{Missed opportunity costs (MOC)}

Costs to predators of foraging in livestock patches can also be increased. Raising or ensuring high missed opportunity costs (MOC) relative to livestock patches should accelerate giving up on livestock. Often overlooked as a mitigation measure, ensuring viable wild prey populations (e.g. via harvest regulations, habitat restoration, reinforcement or reintroduction) is pivotal in sustaining large carnivore populations and minimising livestock predation (Meriggi \& Lovari 1996; Polisar et al. 2003; Barja 2009). Predators will increasingly target livestock, which increase in relative value, as wild prey decline (Kolowski \& Holekamp 2006). Low energy state foragers also tend to take higher risks (Brown 1988; Brown, Morgan \& Dow 1992). Ensuring higher predator energy states by maintaining suitable wild prey stocks could reduce the marginal value of livestock as a food source.

Livestock production and the maintenance of wild prey stocks are however most likely best kept somewhat apart. Abundant wild prey in pastoral areas could cause increased livestock predation (Stahl et al. 2001; Bradley \& Pletscher 2005; Amirkhiz et al. 2018). Carnivores are attracted to high quality habitat and conflicts may be more likely to occur where human activities, including livestock farming, overlap (Wilson et al. 2006; Odden et al. 2008). Livestock could be kept away from preferable wildlife habitat or better protected where this is not feasible. Habitat improvement and suitable limitation to wild herbivore harvest could also be employed in areas set aside from pastoralism. Excepting large land owners, this will require regional level intervention. Livestock producers can however make their properties less attractive to wild herbivores, e.g. protecting hay supplies, using livestock guardian dogs, Canis lupus familiaris, or hazing habituated wildlife (Bradley \& Pletscher 2005; Kloppers, St. Clair \& Hurd 2005; Gehring et al. 2010).

Seasonal declines in wild prey availability (MOC) driven by environmental conditions, seasonal migrations and prey habitat use, especially if coinciding with increased stock availability can lead to prey switching and increased livestock predation (Cavalcanti \& Gese 2010; Valeix et al. 2012). In a 
similar fashion the relative value of livestock may increase following seasonal predator food demand and decreases in wild prey vulnerability due to maturing young (Ciucci \& Boitani 1998). Practitioners should accordingly increase other costs (C, P or RI) and avoid increasing potential attractants (e.g. young livestock) during these more vulnerable periods.

Energetic cost $(C)$

The energetic cost (C) of preying on livestock could be increased, especially during periods of vulnerability. Fencing can provide an energetically costly barrier for carnivores to overcome. Fencing, albeit a barrier to wildlife movements, likely reduces losses; however its general efficacy will depend on the problem carnivore's abilities, fence maintenance and the presence of other fence damaging wildlife (Breitenmoser et al. 2005; McManus et al. 2015). Keeping livestock in predator proof corrals at night can efficiently minimise losses, although crowding can necessitate additional health care, and poor maintenance risks severe losses (Breitenmoser et al. 2005; Schiess-Meier et al. 2007; Weise et al. 2018). Corrals and fencing can also be made more disruptive through the addition of perceived or real injury related risk via fladry (Fig.1) and/or electric current (Musiani et al. 2003; Lance et al. 2011).

Livestock attributes could also affect the energetic costs of predation. Young, sick and injured animals may incur minimal energetic costs to hunt and can thus be more vulnerable to predation (Chavez \& Giese 2006; Cavalcanti \& Gese 2010). Producers should monitor and be mindful of herd vulnerability relative to alternative wild prey sources, targeting additional interventions accordingly. Vulnerable livestock, such as sheep, Ovis aries, can also be bonded to or housed with herd animals possessing better defensive capabilities (greater aggression, size, strength, armament). For example, llama's, Lama glama, long-horned cattle, Bos taurus, or donkeys, Equus africanus, can provide protective services by increasing injury related risk (RI) and the energetic costs (C) of accessing livestock (Smith et al. 2000b). Stock breed could perhaps be altered by selecting more agile or defensive breeds, which retain anti-predator behaviour. Anti-predator defence could also be encouraged within current stocks, for example, some producers attribute fewer wolf, Canis lupus, related livestock losses 
to keeping protective mother cows and encouraging defensive herding behaviour, instead of removing

232 protective mothers and allowing herds to fragment across remote areas (H.Z. Anderson, Tom Miner

233 Basin Project, Pers comm).

Predation risk $(P)$ and risk of injury $(R I)$

235

236

237

238

There is good evidence to suggest that animals assess and respond to risk (Lima \& Dill 1990; Creel \& Christianson 2008; Heithaus et al. 2009). Fear ecology suggests such interactions may affect landscape use and foraging (Brown, Laundré \& Gurung 1999; Brown \& Kotler 2007; Laundré, Hernández \& Ripple 2010). The mesopredator release hypothesis suggests predators too have things to fear (Crooks \& Soulé 1999; Ritchie \& Johnson 2009; Newsome et al. 2017). Humans are a key factor that alters the context within which predators exist (Haswell, Kusak \& Hayward 2017). Humans may be viewed as super predators whose presence provides substantial risk to carnivores, consequently modifying predatory behaviour (Smith et al. 2017).

Increase in perceived or actual predation costs (P), as well as risk of injury (RI) from other causes, have received most attention in the development of non-lethal mitigation strategy (See Breitenmoser et al. (2005) and Shivik (2006) for comprehensive reviews). Wild animals, especially predators, can be particularly sensitive to new stimuli; scare devices using disruptive mechanisms such as neophobia, irritation or pain have consequently been utilised as primary repellents (Shivik, Treves \& Callahan 2003; Shivik 2006). Secondary repellents establish a link between a behaviour and a negative outcome through aversive conditioning, e.g. electronic training collars worn by predators or taste aversion collars worn by livestock (Shivik, Treves \& Callahan 2003; Shivik 2006). Excessive use of primary repellents risks habituation whereas secondary repellents can require substantial logistical effort and may need to be regularly reinforced to remain effective (Smith et al. 2000a; Shivik 2006). Harassment (e.g. rubber bullets) may offer simple implementation but linking aversion and behaviour might prove difficult and thereby limit effectiveness; consistent secondary repellents such as electrified fladry may however prove more efficacious in both application and reinforcement 
(Shivik 2006). Use of primary and secondary repellents will depend on local laws, additional conservation concerns, and the ethical views of the practitioner.

258

Manipulating risk perception could still prove useful alongside the provision of direct threats. Visual assessment of habitat and its interaction with escape strategies provides one means by which animals may assess and respond to risk (Wirsing, Cameron \& Heithaus 2010; Kuijper et al. 2013; Camacho 2014). Landscape characteristics, such as vegetative cover or woodlands adjacent to pastures, can be associated with higher levels of livestock predation (Ciucci \& Boitani 1998; Stahl et al. 2001). Mapping risk hotspots could provide an effective decision making tool (Treves et al. 2004).

Animals also assess risk through auditory means (Berger, Swenson \& Persson 2001; Lynch et al. 2015). Many technological scare devices work through visual or auditory disruptive stimuli, e.g. flashing lights, high beam lights, air horns, propane cannons, and sometimes through a combination, e.g. radio activated guard (RAG) boxes. Repellents such as flashing lights can significantly reduce predation but may not be effective against all carnivores (Ohrens, Bonacic \& Treves 2019). Practitioner strategy will need to be context specific as well as adaptive. For example, when nocturnally flashing lights were applied to livestock bomas (protective night pens) in Kenya, Lions, Panthera leo, switched to attacking bomas where intervention was not implemented, and subsequently, when installation of lights increased, shifted to diurnal attacks (Lesilau et al. 2018).

The scent of dominant predators can communicate increased risk to carnivores (Leo, Reading \& Letnic 2015; Haswell et al. 2018). Manipulation of scent could be useful in manipulating predator landscape use but may not always yield intended outcomes due to the context in which scent is encountered (Jones et al. 2016). Placement of scent manipulations could ideally be optimised if context relations are understood, i.e. what scent to place, when, where and how much. Identifying effective components of olfactory communication such as producer diet or social status and their associated compounds could also improve effectiveness (Parsons et al. 2018).

Direct presence of predation and injury risk are likely to elicit stronger responses than cues such as olfaction alone (Scheinin et al. 2006; Vanak, Thaker \& Gompper 2009). Livestock guardian animals 
may provide multiple benefits through olfactory and auditory risk cue provision as well as direct presence (van Bommel \& Johnson 2012; McManus et al. 2015). Livestock guardian dogs (Fig.2) can increase predation risk $(\mathrm{P})$ and intimidate predators by protecting stock directly or creating landscapes of fear when used in a patrolling manor (Rigg 2001; Hansen, Staaland \& Ringso 2002; Rigg et al. 2011). Guardian dogs may protect livestock without entirely excluding predators from foraging nearby (Allen et al. 2017). In some circumstances, the use of dogs may be spatially or seasonally problematic depending on wildlife sensitive periods, farming practices and other landscape users e.g. hikers or hunters. Livestock guardian dogs show good potential in mitigating pastoral wildlife conflict but the most effective methods for their use requires further investigation (Gehring, VerCauteren \& Landry 2010; Gehring et al. 2010; Lescureux \& Linnell 2014).

\section{Conclusions}

Scientific theory can offer useful frameworks for applied conservation issues. Understanding patterns and processes involved in livestock predation, developing effective ways to mitigate predation and rigorously testing non-lethal deterrents have been identified as areas requiring advancement (Breck \& Meier 2004; Purcell et al. 2012; Eklund et al. 2017). All could be assisted by inclusion of foraging theory and risk ecology frameworks as part of study design and theoretical underpinning for management decision making.

It is important to understand that there is no 'silver bullet' strategy (Treves et al. 2006). Interactions between species are context-dependent (Haswell, Kusak \& Hayward 2017). Success of non-lethal tools will vary in time and space depending on the structure of the quitting harvest rate model in a given scenario. There will of course also be scenarios where animals don't follow the model or nonlethal tools aren't applied correctly. Habituation to repellent devices can also prove problematic (Musiani et al. 2003; Shivik 2006; Lance et al. 2011). Adaptive, location and time specific management strategies are likely to prove most effective in ensuring protection techniques do not lose risk value (Stone et al. 2017; van Eeden et al. 2018a). Understanding changes in model components 
will also help with timing management interventions, e.g. increase in $\mathrm{P}$ in unison with seasonal fluctuations of MOC and predator nutritional needs. Identifying areas where predation likelihood is higher and circumstances tip the equation in favour of harvest will prove additionally useful (Treves et al. 2004; Treves \& Rabenhorst 2017). Foraging theory can provide a useful framework for studying and managing livestock predation. If components of Brown's (1988) model are understood and can be manipulated through management practices then it should be feasible to tip the equation in favour of coexistence.

\section{Acknowledgements}

This work did not receive any specific grant from funding agencies in the public, commercial, or notfor-profit sectors. We would like to thank livestock producers who employ non-lethal predator management strategies and attempt to share the landscape with wildlife. Thanks to Bangor University and Defenders of Wildlife for their support of the authors. Thanks to two anonymous reviewers for their comments which strengthened the manuscript. We would also like to thank the organisers of the $3^{\text {rd }}$ International Compassionate Conservation Conference for providing the opportunity for which this idea was conceived.

\section{Compliance with ethical standards}

The authors declare that they have no conflict of interest in the authorship of this article. Use of product or corporation names is for descriptive purposes only and implies no endorsement by any author or affiliation.

\section{References}

Allen, L.R., Stewart-Moore, N., Byrne, D. \& Allen, B.L. (2017) Guardian dogs protect sheep by guarding sheep, not by establishing territories and excluding predators. Anim Prod Sci, 57, $1118-1127$. 
Amirkhiz, R.G., Frey, J.K., Cain, J.W., Breck, S.W. \& Bergman, D.L. (2018) Predicting spatial factors associated with cattle depredations by the Mexican wolf (Canis lupus baileyi) with recommendations for depredation risk modeling. Biol Conserv, 224, 327-335.

Anthony, B. (2007) The dual nature of parks: attitudes of neighbouring communities towards Kruger National Park, South Africa. Environ Conserv, 34, 236-245.

Anthony, B.P., Scott, P. \& Antypas, A. (2010) Sitting on the fence? Policies and practices in managing human-wildlife conflict in Limpopo Province, South Africa. Conserv Soc, 8, 225240.

Bar-On, Y.M., Phillips, R. \& Milo, R. (2018) The biomass distribution on Earth. Proc Natl Acad Sci USA, 115, 6506-6511.

Barja, I. (2009) Prey and prey-age preference by the Iberian wolf Canis lupus signatus in a multipleprey ecosystem. Wildlife Biol, 15, 147-154.

Baroni, L., Cenci, L., Tettamanti, M. \& Berati, M. (2007) Evaluating the environmental impact of various dietary patterns combined with different food production systems. Eur J Clin Nutr, 61, 279-286.

Berger, J., Swenson, J.E. \& Persson, I.L. (2001) Recolonizing carnivores and naive prey: conservation lessons from Pleistocene extinctions. Science, 291, 1036-1039.

Berger-Tal, O., Mukherjee, S., Kotler, B.P. \& Brown, J.S. (2009) Look before you leap: is risk of injury a foraging cost? Behav Ecol Sociobiol, 63, 1821-1827.

Bradley, E.H. \& Pletscher, D.H. (2005) Assessing factors related to wolf depredation of cattle in fenced pastures in Montana and Idaho. Wildl Soc Bull, 33, 1256-1265.

Breck, S. \& Meier, T. (2004) Managing wolf depredation in the United States: past, present, and future. Sheep Goat Res J, 19, 41-47.

Breitenmoser, C., Angst, U., Landry, C., Breitenmoser-Würsten, C., Linnell, J.D.C. \& Weber, J.M. (2005) Non-lethal techniques for reducing depredation. In R. Woodroffe, S. Thirgood \& A. Rabinowitz (Eds.), People and Wildlife: Conflict or Coexistence? (pp. 49-71). Cambridge, UK: Cambridge University Press. 
Brown, C., McMorran, R. \& Price, M.F. (2011) Rewilding - A new paradigm for nature conservation in Scotland? Scott Geogr J, 127, 288-314.

Brown, J.S. (1988) Patch use as an indicator of habitat preference, predation risk, and competition. Behav Ecol Sociobiol, 22, 37-47.

Brown, J.S. \& Kotler, B.P. (2007) Foraging and the ecology of fear. In D.W. Stephens, J.S. Brown \& R.C. Ydenberg (Eds.), Foraging Behaviour and Ecology (pp. 438-480). Chicago USA: University of Chicago Press.

Brown, J.S., Laundré, J.W. \& Gurung, M. (1999) The ecology of fear: optimal foraging, game theory, and trophic interactions. J Mammal, 80, 385-399.

Brown, J.S., Morgan, R.A. \& Dow, B.D. (1992) Patch use under predation risk: II. A test with fox squirrels, Sciurus niger. Ann Zool Fennici, 29, 311-318.

Camacho, C. (2014) 'Bodyguard' plants: predator-escape performance influences microhabitat choice by nightjars. Behav Process, 103, 145-149.

Cavalcanti, S.M.C. \& Gese, E.M. (2010) Kill rates and predation patterns of jaguars (Panthera onca) in the southern Pantanal, Brazil. J Mammal, 91, 722-736.

Chapron, G., Kaczensky, P., Linnell, J.D., Von Arx, M., Huber, D., Andrén, H., López-Bao, J.B., Adamec, M., Álvares, F., Anders, O., Balčiauskas, L., Balys, V., Bedő, P., Bego, F., Blanco, J.C., Breitenmoser, U., Brøseth, H., Bufka, L., Bunikyte, R., Ciucci, P., Dutsov, A., Engleder, T., Fuxjäger, C., Groff, C., Holmala, K., Hoxha, B., Iliopoulos, Y., Ionescu, O., Jeremić, J., Jerina, K., Kluth, G., Knauer, F., Kojola, I., Kos, I., Krofel, M., Kubala, J., Kunovac, S., Kusak, J., Kutal, M., Liberg, O., Majić, A., Männil, P., Manz, R., Marboutin, E., Marucco, F., Melovski, D., Mersini, K., Mertzanis, Y., Mysłajek, R.W., Nowak, S., Odden, J., Ozolins, J., Palomero, G., Paunović, M., Persson, J., Potočnik, H., Quenette, P.-Y., Rauer, G., Reinhardt, I., Rigg, R., Ryser, A., Salvatori, V., Skrbinšek, T., Stojanov, A., Swenson, J.E., Szemethy, L., Trajçe, A., Tsingarska-Sedefcheva, E., Váňa, M., Veeroja, R., Wabakken, P., Wölfl, M., Wölfl, S., Zimmermann, F., Zlatanova, D. \& Boitani, L. (2014) Recovery of large carnivores in Europe's modern human-dominated landscapes. Science, 346 1517-1519.

Charnov, E.L. (1976) Optimal foraging, the marginal value theorem. Theor Popul Biol, 9, 129-136. 
Chavez, A.S., Gese, E.M. \& Krannich, R.S. (2005) Attitudes of rural landowners toward wolves in northwestern Minnesota. Wildlife Soc B, 33, 517-527.

Chavez, A.S. \& Giese, E.M. (2006) Landscape use and movements of wolves in relation to livestock in a wildland-agriculture matrix. $J$ Wildl Manage, 70, 1079-1086.

Ciucci, P. \& Boitani, L. (1998) Wolf and dog depredation on livestock in central Italy. Wildl Soc Bull, 26, 504-514.

Ciucci, P., Boitani, L., Francisci, F. \& Andreoli, G. (1997) Home range, activity and movements of a wolf pack in central Italy. J Zool Lond, 243, 803-819.

Creel, S. \& Christianson, D. (2008) Relationships between direct predation and risk effects. Trends Ecol Evol, 23, 194-201.

Crooks, K.R. \& Soulé, M.E. (1999) Mesopredator release and avifaunal extinctions in a fragmented system. Nature, 400, 563-566.

Dar, N.I., Minhas, R.A., Zaman, Q. \& Linkie, M. (2009) Predicting the patterns, perceptions and causes of human-carnivore conflict in and around Machiara National Park, Pakistan. Biol Conserv, 142, 2076-2082.

Deemer, D.R. \& Lobao, L.M. (2011) Public concern with farm-animal welfare: religion, politics, and human disadvantage in the food sector. Rural Sociol, 76, 167-196.

Eggermann, J., da Costa, G.F., Guerra, A.M., Kirchner, W.H. \& Petrucci-Fonseca, F. (2011) Presence of Iberian wolf (Canis lupus signatus) in relation to land cover, livestock and human influence in Portugal. Mamm Biol, 76, 217-221.

Eklund, A., López-Bao, J.V., Tourani, M., Chapron, G. \& Frank, J. (2017) Limited evidence on the effectiveness of interventions to reduce livestock predation by large carnivores. Sci Rep, 7 , 2097.

Eldridge, D.J., Poore, A.G.B., Ruiz-Colmenero, M., Letnic, M. \& Soliveres, S. (2016) Ecosystem structure, function, and composition in rangelands are negatively affected by livestock grazing. Ecol Appl, 26, 1273-1283.

Emlen, J.M. (1966) The role of time and energy in food preference. Am Nat, 100, 611-617. 
Eshel, G., Shepon, A., Makov, T. \& Milo, R. (2014) Land, irrigation water, greenhouse gas, and reactive nitrogen burdens of meat, eggs, and dairy production in the United States. Proc Natl Acad Sci USA, 111, 11996-12001.

Franzluebbers, A.J., Paine, L.K., Winsten, J.R., Krome, M., Sanderson, M.A., Ogles, K. \& Thompson, D. (2012) Well-managed grazing systems: a forgotten hero of conservation. J Soil Water Conserv, 67, 100A-104A.

Gehring, T.M., VerCauteren, K.C. \& Landry, J.-M. (2010) Livestock protection dogs in the 21st Century: is an ancient tool relevant to modern conservation challenges? Bioscience, 60, 299308.

Gehring, T.M., VerCauteren, K.C., Provost, M.L. \& Cellar, A.C. (2010) Utility of livestockprotection dogs for deterring wildlife from cattle farms. Wildl Res, 37, 715-721.

Gottdenker, N.L., Streicker, D.G., Faust, C.L. \& Carroll, C.R. (2014) Anthropogenic land use change and infectious diseases: a review of the evidence. Ecohealth, 11, 619-632.

Hallström, E., Carlsson-Kanyama, A. \& Börjesson, P. (2015) Environmental impact of dietary change: a systematic review. J Clean Prod, 91, 1-11.

Hansen, I., Staaland, T. \& Ringso, A. (2002) Patrolling with livestock guard dogs: a potential method to reduce predation on sheep. Acta Agric Scand Sect A-Anim Sci, 52, 43-48.

Haswell, P.M., Jones, K.A., Kusak, J. \& Hayward, M.W. (2018) Fear, foraging and olfaction: how mesopredators avoid costly interactions with apex predators. Oecologia, 187, 573-583.

Haswell, P.M., Kusak, J. \& Hayward, M.W. (2017) Large carnivore impacts are context-dependent. Food Webs, 12, 3-13.

Hayward, M.W., Porter, L., Lanszki, J., Kamler, J.F., Beck, J.M., Kerley, G.I.H., Macdonald, D.W., Montgomery, R.A., Parker, D.M., Scott, D.M., O'Brien, J. \& Yarnell, R.W. (2017) Factors affecting the prey preferences of jackals (Canidae). Mamm Biol, 85, 70-82.

Heithaus, M.R., Wirsing, A.J., Burkholder, D., Thomson, J. \& Dill, L.M. (2009) Towards a predictive framework for predator risk effects: the interaction of landscape features and prey escape tactics. J Anim Ecol, 78, 556-562. 
Holmes, M. (2016) 'We'll have what they're having', cultural identity through diet in the English Saxon Period. Environ Archaeol, 21, 59-78.

Hudson, J.A., Frewer, L.J., Jones, G., Brereton, P.A., Whittingham, M.J. \& Stewart, G. (2017) The agri-food chain and antimicrobial resistance: a review. Trends Food Sci Technol, 69, 131-147.

Jones, M.E., Apfelbach, R., Banks, P.B., Cameron, E.Z., Dickman, C.R., Frank, A., McLean, S., McGregor, I.S., Müller-Schwarze, D., Parsons, M.H., Sparrow, E. \& Blumstein, D.T. (2016) A nose for death: integrating trophic and informational networks for conservation and management. Front Ecol Evol, 4, 124.

Kearney, J. (2010) Food consumption trends and drivers. Philos Trans R Soc B-Biol Sci, 365, 2793 2807.

Kloppers, E.L., St. Clair, C.C. \& Hurd, T.E. (2005) Predator-resembling aversive conditioning for managing habituated wildlife. Ecol Soc, 10, 31.

Kolowski, J.M. \& Holekamp, K.E. (2006) Spatial, temporal, and physical characteristics of livestock depredations by large carnivores along a Kenyan reserve border. Biol Conserv, 128, 529-541.

Kolowski, J.M. \& Holekamp, K.E. (2008) Effects of an open refuse pit on space use patterns of spotted hyenas. Afr J Ecol, 46, 341-349.

Kuijper, D.P.J., de Kleine, C., Churski, M., van Hooft, P., Bubnicki, J. \& Jedrzejewska, B. (2013) Landscape of fear in Europe: wolves affect spatial patterns of ungulate browsing in Bialowieza Primeval Forest, Poland. Ecography, 36, 1263-1275.

Lance, N.J., Breck, S.W., Sime, C., Callahan, P. \& Shivik, J.A. (2011) Biological, technical, and social aspects of applying electrified fladry for livestock protection from wolves (Canis lupus). Wildlife Res, 37, 708-714.

Latham, J. (1999) Interspecific interactions of ungulates in European forests: an overview. For Ecol Manage, 120, 13-21.

Laundré, J.W., Hernández, L. \& Ripple, W.J. (2010) The landscape of fear: ecological implications of being afraid. Open Ecol J, 3, 1-7.

Leo, V., Reading, R.P. \& Letnic, M. (2015) Interference competition: odours of an apex predator and conspecifics influence resource acquisition by red foxes. Oecologia, 179, 1033-1040. 
Lescureux, N. \& Linnell, J.D. (2014) Warring brothers: the complex interactions between wolves (Canis lupus) and dogs (Canis familiaris) in a conservation context. Biol Conserv, 171, 232245.

Lesilau, F., Fonck, M., Gatta, M., Musyoki, C., van't Zelfde, M., Persoon, G.A., Musters, K.C.J.M., de Snoo, G.R. \& de Iongh, H.H. (2018) Effectiveness of a LED flashlight technique in reducing livestock depredation by lions (Panthera leo) around Nairobi National Park, Kenya. PLoS ONE, 13, e0190898.

Lima, S.L. \& Dill, L.M. (1990) Behavioral decisions made under the risk of predation: a review and prospectus. Can J Zool, 68, 619-640.

Lynch, E., Northrup, J.M., McKenna, M.F., Anderson, C.R., Angeloni, L. \& Wittemyer, G. (2015) Landscape and anthropogenic features influence the use of auditory vigilance by mule deer. Behav Ecol, 26, 75-82.

Lyngdoh, S., Shrotriya, S., Goyal, S.P., Clements, H., Hayward, M.W. \& Habib, B. (2014) Prey preferences of the snow leopard (Panthera uncia): regional diet specificity holds global significance for conservation. PLOS ONE, 9, e100071.

MacArthur, R.H. \& Pianka, E.R. (1966) On optimal use of a patchy environment. Am Nat, 100, 603609.

Macdonald, D.W. \& Baker, S.E. (2004) Non-lethal control of fox predation: the potential of generalised aversion. Anim Welfare, 13, 77-85.

McClure, S.B. (2015) The pastoral effect niche construction, domestic animals, and the spread of farming in Europe. Curr Anthropol, 56, 901-910.

McManus, J.S., Dickman, A.J., Gaynor, D., Smuts, B.H. \& Macdonald, D.W. (2015) Dead or alive? Comparing costs and benefits of lethal and non-lethal human-wildlife conflict mitigation on livestock farms. Oryx, 49, 687-695.

Meriggi, A. \& Lovari, S. (1996) A review of wolf predation in southern Europe: does the wolf prefer wild prey to livestock? J Appl Ecol, 33, 1561-1571.

Minnie, L., Gaylard, A. \& Kerley, G.I.H. (2016) Compensatory life-history responses of a mesopredator may undermine carnivore management efforts. J Appl Ecol, 53, 379-387. 
Minnie, L., Gaylard, A. \& Kerley, G.I.H. (2017) Corrigendum. J Appl Ecol, 54, 1008-1009.

Morehouse, A.T. \& Boyce, M.S. (2017) Troublemaking carnivores: conflicts with humans in a diverse assemblage of large carnivores. Ecol Soc, 22, 4.

Musiani, M., Mamo, C., Boitani, L., Callaghan, C., Gates, C.C., Mattei, L., Visalberghi, E., Breck, S. \& Volpi, G. (2003) Wolf depredation trends and the use of fladry barriers to protect livestock in western North America. Conserv Biol, 17, 1538-1547.

Newsome, T.M., Ballard, G.A., Fleming, P.J.S., van de Ven, R., Story, G.L. \& Dickman, C.R. (2014) Human-resource subsidies alter the dietary preferences of a mammalian top predator. Oecologia, 175, 139-150.

Newsome, T.M., Greenville, A.C., Ćirović, D., Dickman, C.R., Johnson, C.N., Krofel, M., Letnic, M., Ripple, W.J., Ritchie, E.G., Stoyanov, S. \& Wirsing, A.J. (2017) Top predators constrain mesopredator distributions. Nat Commun, 8, 15469.

Odden, J., Herfindal, I., Linnell, J.D.C. \& Andersen, R. (2008) Vulnerability of domestic sheep to lynx depredation in relation to roe deer density. J Wildlife Manage, 72, 276-282.

Ohrens, O., Bonacic, C. \& Treves, A. (2019) Non-lethal defense of livestock against predators: flashing lights deter puma attacks in Chile. Front Ecol Environ, 17, 32-38.

Parsons, M.H., Apfelbach, R., Banks, P.B., Cameron, E.Z., Dickman, C.R., Frank, A.S., Jones, M.E., McGregor, I.S., McLean, S., Müller-Schwarze, D. \& Sparrow, E.E. (2018) Biologically meaningful scents: a framework for understanding predator-prey research across disciplines. Biol Rev, 93, 98-114.

Pimenta, V., Barroso, I., Boitani, L. \& Beja, P. (2017) Wolf predation on cattle in Portugal: assessing the effects of husbandry systems. Biol Conserv, 207, 17-26.

Pitikoe, S. (2017) Basotho herders learn through culture and social interaction. Learn Cult Soc Interact, 13, 104-112.

Polisar, J., Maxit, I., Scognamillo, D., Farrell, L., Sunquist, M.E. \& Eisenberg, J.F. (2003) Jaguars, pumas, their prey base, and cattle ranching: ecological interpretations of a management problem. Biol Conserv, 109, 297-310. 
Poore, J. \& Nemecek, T. (2018) Reducing food's environmental impacts through producers and consumers. Science, 360, 987-992.

Purcell, B.V., Glover, A., Mulley, R.C. \& Close, R.L. (2012) Euro-Australian culture and dilemmas within the science and management of the dingo, Canis lupus dingo. In P. Banks, D. Lunney \& C. Dickman (Eds.), Science under siege: zoology under threat (pp. 114-120). Mosman, NSW, Australia: Royal Zoological Society of New South Wales.

Reading, C.J. \& Jofre, G.M. (2015) Habitat use by smooth snakes on lowland heath managed using 'conservation grazing'. Herpetolog J, 25, 225-231.

Rigg, R. (2001) Livestock guarding dogs: their current use worldwide. IUCN/SSC Canid Specialist Group Occasional Paper, 1, 1-133.

Rigg, R., Findo, S., Wechselberger, M., Gorman, M.L., Sillero-Zubiri, C. \& Macdonald, D.W. (2011) Mitigating carnivore-livestock conflict in Europe: lessons from Slovakia. Oryx, 45, 272-280.

Ripple, W.J., Estes, J.A., Beschta, R.L., Wilmers, C.C., Ritchie, E.G., Hebblewhite, M., Berger, J., Elmhagen, B., Letnic, M., Nelson, M.P., Schmitz, O.J., Smith, D.W., Wallach, A.D. \& Wirsing, A.J. (2014) Status and ecological effects of the world's largest carnivores. Science, $343,1241484$.

Ripple, W.J., Wolf, C., Newsome, T.M., Galetti, M., Alamgir, M., Crist, E., Mahmoud, M.I. \& Laurance, W.F. (2017) World scientists' warning to humanity: a second notice. BioScience, 67, 1026-1028.

Ritchie, E.G. \& Johnson, C., N. (2009) Predator interactions, mesopredator release and biodiversity conservation. Ecol Lett, 12, 982-998.

Scasta, J.D., Stam, B. \& Windh, J.L. (2017) Rancher-reported efficacy of lethal and non-lethal livestock predation mitigation strategies for a suite of carnivores. Sci Rep, 7, 14105.

Scheinin, S., Yom-Tov, Y., Motro, U. \& Geffen, E. (2006) Behavioural responses of red foxes to an increase in the presence of golden jackals: a field experiment. Anim Behav, 71, 577-584.

Schiess-Meier, M., Ramsauer, S., Gabanapelo, T. \& Konig, B. (2007) Livestock predation - insights from problem animal control registers in Botswana. J Wildl Manage, 71, 1267-1274. 
Sharps, E., Garbutt, A., Hiddink, J.G., Smart, J. \& Skov, M.W. (2016) Light grazing of saltmarshes increases the availability of nest sites for common redshank Tringa totanus, but reduces their quality. Agric Ecosyst Environ, 221, 71-78.

Shelton, M. (2004) Predation and livestock production-perspective and overview. Sheep Goat Res J, 19, 2-6.

Shivik, J. (2006) Tools for the edge: what's new for conserving carnivores. Bioscience, 56, 253-258.

Shivik, J.A., Treves, A. \& Callahan, P. (2003) Non-lethal techniques for managing predation: primary and secondary repellents. Conserv Biol, 17, 1531-1537.

Smith, J.A., Suraci, J.P., Clinchy, M., Crawford, A., Roberts, D., Zanette, L.Y. \& Wilmers, C.C. (2017) Fear of the human 'super predator' reduces feeding time in large carnivores. Proc $R$ Soc B Biol Sci, 284, 20170433.

Smith, M.E., Linnell, J.D.C., Odden, J. \& Swenson, J.E. (2000a) Review of methods to reduce livestock depredation II. Aversive conditioning, deterrents and repellents. Acta Agr Scand AAn, 50, 304-315.

Smith, M.E., Linnell, J.D.C., Odden, J. \& Swenson, J.E. (2000b) Review of methods to reduce livestock depredation: I. Guardian animals. Acta Agr Scand A-An, 50, 279-290.

Springmann, M., Mason-D'Croz, D., Robinson, S., Wiebe, K., Godfray, H.C.J., Rayner, M. \& Scarborough, P. (2017) Mitigation potential and global health impacts from emissions pricing of food commodities. Nat Clim Chang, 7, 69-74.

Stahl, P., Vandel, J.M., Herrenschmidt, V. \& Migot, P. (2001) Predation on livestock by an expanding reintroduced lynx population: long-term trend and spatial variability. J Appl Ecol, 38, 674687.

Stone, S.A., Breck, S.W., Timberlake, J., Haswell, P.M., Najera, F., Bean, B.S. \& Thornhill, D.J. (2017) Adaptive use of nonlethal strategies for minimizing wolf-sheep conflict in Idaho. $J$ Mammal, 98, 33-44.

Thompson, R.C.A. (2013) Parasite zoonoses and wildlife: one health, spillover and human activity. Int J Parasitol, 43, 1079-1088. 
Treves, A., Krofel, M. \& McManus, J. (2016) Predator control should not be a shot in the dark. Front Ecol Environ, 14, 380-388.

Treves, A., Naughton-Treves, L., Harper, E.K., Mladenoff, D.J., Rose, R.A., Sickley, T.A. \& Wydeven, A.P. (2004) Predicting human-carnivore conflict: a spatial model derived from 25 years of data on wolf predation on livestock. Conserv Biol, 18, 114-125.

Treves, A. \& Rabenhorst, M.F. (2017) Risk map for wolf threats to livestock still predictive 5 years after construction. PLOS ONE, 12, e0180043.

Treves, A., Wallace, R.B., Naughton-Treves, L. \& Morales, A. (2006) Co-managing human-wildlife conflicts: a review. Hum Dimens Wildl, 11, 383-396.

Valeix, M., Hemson, G., Loveridge, A.J., Mills, G. \& Macdonald, D.W.(2012) Behavioural adjustments of a large carnivore to access secondary prey in a human-dominated landscape. $J$ Appl Ecol, 49, 73-81.

van Bommel, L. \& Johnson, C.N. (2012) Good dog! Using livestock guardian dogs to protect livestock from predators in Australia's extensive grazing systems. Wildlife Res, 39, 220-229.

van Eeden, L.M., Crowther, M.S., Dickman, C.R., Macdonald, D.W., Ripple, W.J., Ritchie, E.G. \& Newsome, T.M. (2018a) Managing conflict between large carnivores and livestock. Conserv Biol, 32, 26-34.

van Eeden, L.M., Eklund, A., Miller, J.R.B., Lopez-Bao, J.V., Chapron, G., Cejtin, M.R., Crowther, M.S., Dickman, C.R., Frank, J., Krofel, M., Macdonald, D.W., McManus, J., Meyer, T.K., Middleton, A.D., Newsome, T.M., Ripple, W.J., Ritchie, E.G., Schmitz, O.J., Stoner, K.J., Tourani, M. \& Treves, A. (2018b) Carnivore conservation needs evidence-based livestock protection. PLoS Biol, 16, e2005577.

Vanak, A.T., Thaker, M. \& Gompper, M.E. (2009) Experimental examination of behavioural interactions between free-ranging wild and domestic canids. Behav Ecol Sociobiol, 64, 279287.

Wallach, A.D., Johnson, C.N., Ritchie, E.G. \& O'Neill, A.J. (2010) Predator control promotes invasive dominated ecological states. Ecol Lett, 13, 1008-1018. 
Wallach, A.D., Ritchie, E.G., Read, J. \& O'Neill, A.J. (2009) More than mere numbers: the impact of lethal control on the social stability of a top-order predator. PLoS ONE, 4, e6861.

Weise, F.J., Hayward, M.W., Aguirre, R.C., Tomeletso, M., Gadimang, P., Somers, M.J. \& Stein, A.B. (2018) Size, shape and maintenance matter: a critical appraisal of a global carnivore conflict mitigation strategy - livestock protection kraals in northern Botswana. Biol Conserv, 225, 88-97.

Westhoek, H., Lesschen, J.P., Rood, T., Wagner, S., De Marco, A., Murphy-Bokern, D., Leip, A., van Grinsven, H., Sutton, M.A. \& Oenema, O. (2014) Food choices, health and environment: effects of cutting Europe's meat and dairy intake. Global Environ Chang, 26, 196-205.

Wicks, S. \& Allen, B.L. (2012, February) Returns on investment in wild dog management: beef production in the South Australian arid lands. Paper presented at the 56th Australian Agricultural Resource Economics Society conference, Fremantle,Western Australia.

Wilson, S.M., Madel, M.J., Mattson, D.J., Graham, J.M. \& Merrill, T. (2006) Landscape conditions predisposing grizzly bears to conflicts on private agricultural lands in the western USA. Biol Conserv, 130, 47-59.

Wirsing, A.J., Cameron, K.E. \& Heithaus, M.R. (2010) Spatial responses to predators vary with prey escape mode. Anim Behav, 79, 531-537.

WWF (2016) Living Planet Report 2016. Risk and resilience in a new era. Gland, Switzerland: WWF International. 
Table 1. Management options for reducing livestock predation utilising Brown's (1988) quitting harvest rate model, $\mathbf{H}=\mathbf{C}+\mathbf{P}+\mathbf{M O C}$. H $=$ harvest rate, food available per unit time, $\mathrm{C}=$ energetic costs, $\mathrm{P}=$ predation costs, $\mathrm{MOC}=$ missed opportunity costs, alternative fitness enhancing activities e.g. foraging elsewhere, we also add RI = risk of injury. Predators should give up foraging from patches of livestock when the available gains (H) are equal to or less than the costs $(\mathrm{C}+\mathrm{P}+\mathrm{RI}+\mathrm{MOC})$. Managers can manipulate and alter components of the model in order to manipulate predator behaviour, reducing livestock harvest or preventing it beginning in the first place. 


\section{Livestock predation management}

\section{Decrease $\mathrm{H}$}

Reduce herd size, remove carcasses, remove anthropogenic food sources, any intervention which increases the time taken for predation

\begin{tabular}{|c|c|c|}
\hline Increase MOC & Increase $\mathrm{P}$ or RI & \\
\hline $\begin{array}{l}\text { Ensure wild prey stocks } \\
\text { - } \quad \text { Ensure suitable habitat and access to } \\
\text { forage } \\
\text { - } \quad \text { Decrease wild herbivore harvest } \\
\text { - } \quad \text { Keep wild prey and livestock separate } \\
\text { - } \quad \text { Deter wild prey from pastoral areas } \\
\text { Monitor seasonal fluctuations in wild prey } \\
\text { - Increase P, RI or C if wild prey stocks } \\
\text { decline, become less accessible to } \\
\text { predators or if predator food needs } \\
\text { increase e.g. when predator young are } \\
\text { weaned }\end{array}$ & $\begin{array}{l}\text { Guardians } \\
\text { - } \quad \text { Use when possible. Humans, dogs or } \\
\text { other animals e.g. donkeys } \\
\text { - } \quad \text { Use stock with natural defences } \\
\text { - } \quad \text { Ensure appropriate numbers and } \\
\text { behaviour } \\
\text { - } \quad \text { Increase use when needed e.g. during } \\
\text { mobile grazing } \\
\text { Scare devices / risk cues e.g. air horn } \\
-\quad \text { Avoid predator habituation } \\
-\quad \text { Use sporadically and when most needed } \\
-\quad \text { Ensure stock are not startled by devices } \\
\quad \text { and are habituated } \\
\text { Aversive conditioning e.g. taste aversion } \\
\text { collars worn by stock } \\
\text { - Ensure reinforcement }\end{array}$ & $\begin{array}{l}\text { Fencing } \\
\text { - Use corrals when vulnerable e.g. at night } \\
\text { or during lambing } \\
\text { - Consider solid stationary or electric } \\
\text { mobile corrals as well as positioning } \\
\text { - } \quad \text { Apply additional deterrents (P or RI) } \\
\text { when needed e.g. fladry } \\
\text { Livestock attributes } \\
\text { - Use more agile \& less docile livestock } \\
\text { - } \quad \text { Use stock with natural defences e.g. } \\
\text { armament or behaviour } \\
\text { - Breed for attributes } \\
\text { - Herding regime, dispersed or herded } \\
\text { Guardian patrols } \\
\text { - Increase when needed e.g. when predator } \\
\quad \text { young are weaned }\end{array}$ \\
\hline
\end{tabular}

\section{Additional considerations}

\section{Terrain}

- Avoid known hotspots or landscape contexts where livestock predation is more likely

- If unavoidable increase P, RI or C
Predator monitoring

- Avoid areas well visited by predators e.g. known breeding sites

- Increase P, RI or C when predators are in the vicinity 


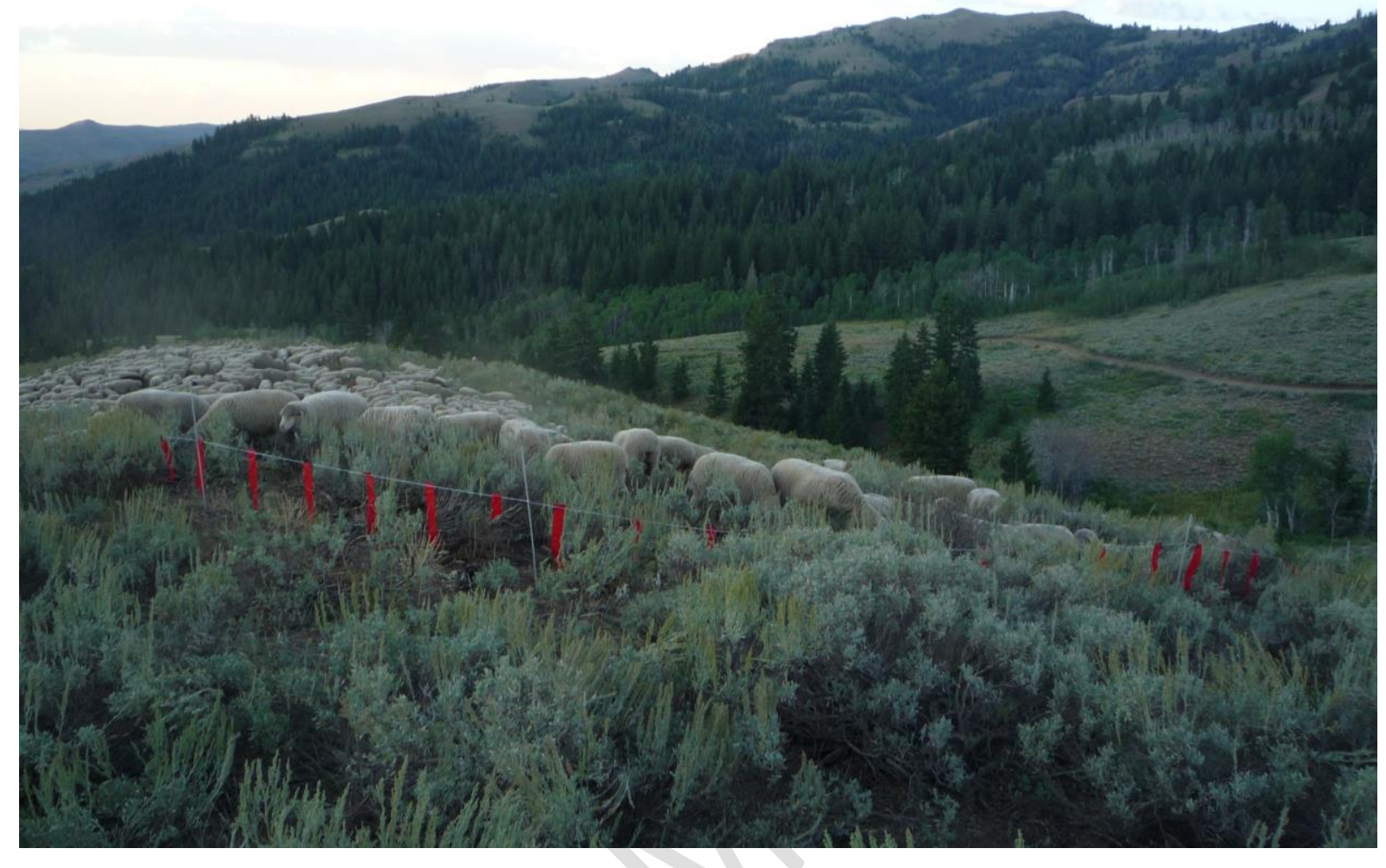

644 Fig 1. Sheep in a temporary night time corral made of electrified fladry as part of the wood river wolf 645 project in Blaine County, Idaho.

646

647

648

649

650

651

652 


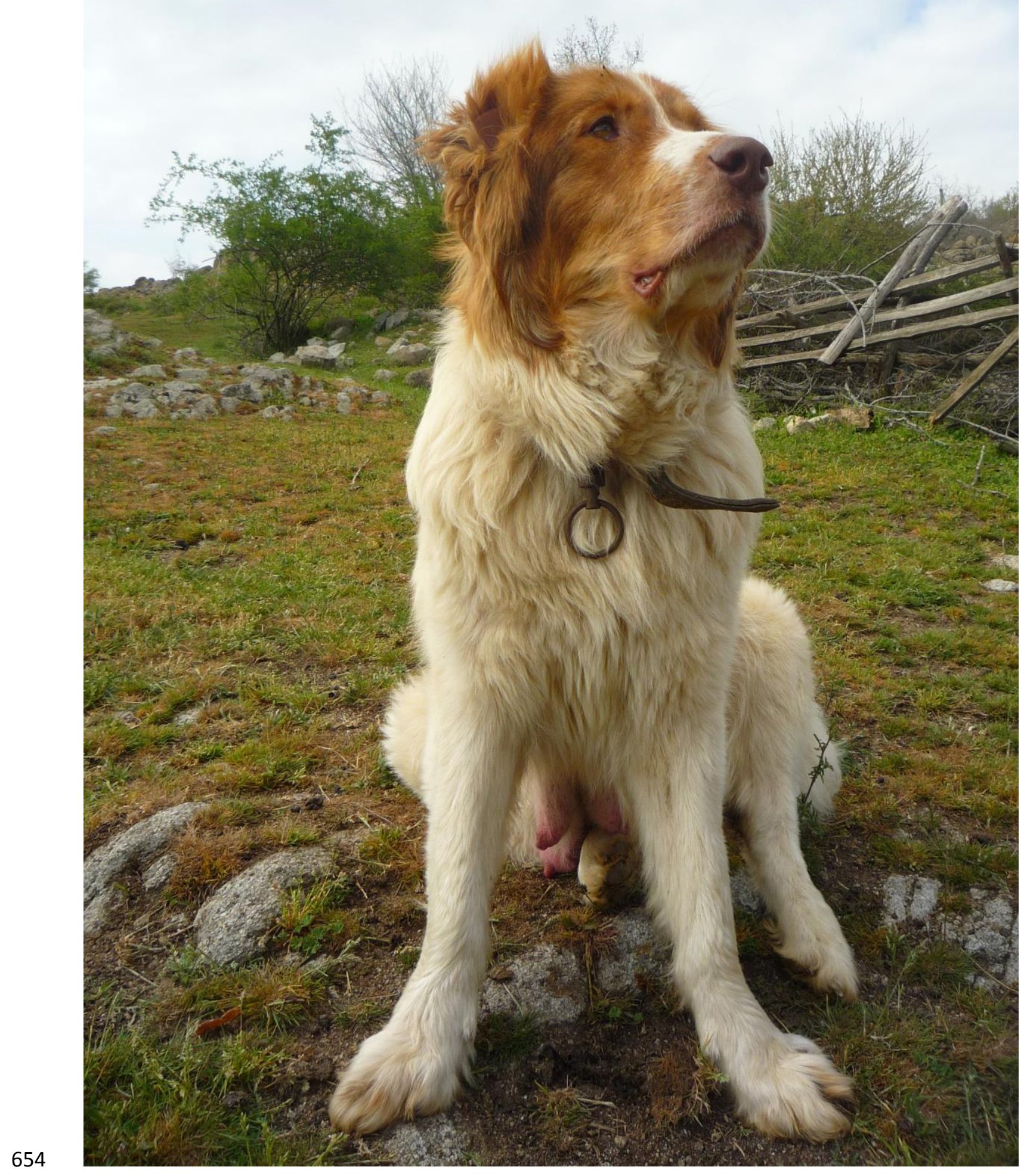

655 Fig 2. Livestock guardian dogs can be raised with and kept with stock or used in a patrolling capacity

656 with a handler or range rider. Karakachan female pictured, a rare breed being conserved by S.

657 Sedefchev, Bulgarian Biodiversity Preservation Society, Semperviva. 